\title{
SAHANA PRADHAN IN THE POLITICS OF NEPAL
}

\section{Dhakaram Sapkota*}

\section{ABSTRACT}

Sahana Pradhan is the top most female leader in the politics of Nepal. She had to struggle a lot to stand at the level. As there was the autocratic Rana regime for more than a century, political awareness could not be developed in general public. At that time it was the great challenge for a woman to be involved in politics. Besides this, Sahana Pradhan had established her own identity by participating actively in student politics against the movement of Rana regime. She remained busy in family affairs rather than politics when she got marriage with founding general secretary of NCP, Pushpalal in 2009BS. Likewise, she joined the Tribhuvan University as the lecturer which was her obligation rather than the interest. But that obligation also got stopped due to politics. After the death of Pushpalal, she started to hold the leadership of the party and got success to be the president of Leftist Union in 2046BS. CPN (UML) which was formed by the integration of CPN (ML) and CPN (Marxism) in 2047BS, got the opportunity to lead the government as the largest party of the country in midterm election of 2051BS. After the split of CPN (UML) all the political enthusiasm got stopped. However, the name Sahana Pradhan got introduced in the history of Nepali Politics.

Keywords: Integration, leftist union, citizen rights, rehabilitation, civil disobedience, barbarity.

\section{INTRODUCTION AND OBJECTIVE}

In 1903BS there was a court massacre in Nepal. After that incident, there was the rise of Rana regime. After that Rana regime got empowered as almost all courtiers were killed who were near regime except kunwar family in massacre like Bhandarkhal and Aaulo. Ascending from Kunwar to Rana caste the descendents of Janga Bahadur Rana had exploited and done injustice to the people by being primeminister and Shree 3 Maharaj. People were fully discarded from political rights and freedom. People were badly subjugated who used to raise voice for civil rights. In this process, many of them had to lose their lives; spend life in jail. Although the domination of Rana was seen since the beginning of Rana regime, people were being against it inwardly. Rana regime was replaced by the democracy in 2007BS

* Dr. Sapkota is a Lecturer, Ratna Rajya Laxmi Campus, Bhrikutimandap, TU. 
as the political parties and general public started the movement from their side. The king stepped over the democracy which was brought by the king and public together in 2017BS and it was reestablished in 2046BS through the movement against the royal power. In 2062/63Bs, there was the second public movement as the reestablished democracy was taken over in 2061BS which ended the monarchy forever. The article is base on how Sahana Pradhan's role was in these political events.

\section{METHODOLOGY}

This article is based on the primary and secondary sources of the data and information. The explanation method is applied as the article seems more reliable through the collected data and the factual information. Along with this different newspapers, opening statement of party and journals are also used as the source. The make these sources reliable, the interviews were done with the contemporary leaders. As the article is based on historical subjects explanation, descriptive and analytical methods are adopted.

\section{ANALYSIS}

Sahana Pradhan was born in 1984BS, Asar 27 in Asan, Kathmandu. Her father Shankar Lal Pradhan had gone to Barma for business. Sahana Pradhan had gone to Barma with her father at the age of 2 years as her mother Ranbhadevi died. She had spent some of her childhood years in Memeu City, Barma which was full of beauty in nature and environment. At that time, that city in Barma was the place for English.

The educational institutions there were comparatively better and qualified than others where the awareness activities of the active society for freedom used to be held. (Gyanwali, 2065:111). The family returned back in Nepal in 2001BS due to the fearful environment of World War II. At that time there was Rana regime. During the period in Nepal it was difficult for men to gain education; talking about women it was rare. However, Sahana Pradhan who was well awared about education continued her education in Nepal, passed SLC and got admission in Trichandra College. As she was from the political awared family background, along with her study she got involved in politics too.

Sahana Pradhan had been involving in the movement against Rana regime since her student life. In 2004BS, Baisakh 14, there was the movement for the sake of citizen freedom and political rights in all three cities of Kathmandu Valley. For this she had come on the road with the 
first and open slogans like - Citizen rights must be gained, We are ready to do and die, No afraid of bullet, against the rana regime in the history of Nepal (Khanal, 2068 Falgun-Chaitra: 7). In that movement there was the participation of thousands of people. Rana ruler had arrested 176 people from the mass. Among them she was also one (Gyanwali, 2065:112). This was the beginning of the women participation in jail (participation of women in Politics, 2052:54).

In 2004BS Baisakh 17 Kanya School was established as the voice was raised for the rights of education for daughter and the school for them. In Nepal, in 2003BS, thaough the municvipality was established women were subjugated from the voting rights. Women sat at the door to force payment in palace of shree 3 Padma Shamsher for the demand of the rights to select and be selected in the legal law for this Sahana Pradhan fast strike for 15 days (The Kathmandu Post, September 23, 2014). Finally, Rana prime minister and shree 3 king Padma Samsher were obliged to accept the demand. (Tumwahangfe, 2059:41). In this way, Sahana Pradhan seems to have the active participation in politics since her student life.

\section{Poltical Responsibility, Unity and Division, Remigration}

Pushpalal and Sahana Pradhan got marriage as they were very close during the meeting for the movement. The family members did not accept them as they got marriage being against their family. They were standing against the rulers in politics along with this they had to face family affairs too which helped her to face the problems. Sahana Pradhan had to take all the responsibilities of family as Pushpalas had to be out of valley for the task of party. From which Pushpalal got out from the family life with full freedom and involved in political life whereas Sahana Pradhan had to be busy in family affairs and have less participation in political activities. At this time she started to teach in TU. But the contemporary government fired her with the charge of helping the student movement of 2032BS (Gyanwaly, 2065:117).

Pushpalal died in 2035BS. After that the party faced difficulties to move a head. In that situation, because of her relation with Pushpalal and the political background since her student life she was forced for the leader of the party by other leaders. She had raised her fist by saying 'I will always attempt to fulfill your unfulfilled dream' at the time of Pushpalal's death. (Gyanwaly, 2065:114). Although she had lost the support of life and had 


\section{SAHANA PRADHAN IN THE POLITICS OF NEPAL}

been out of poliotics for a long time, she had started to show the concern in politics. Her own view, how the situation was created in like this,

I felt that I need to think as the country is in dange. I was not being able to control my self on the force which was created by friends. Finally, I gave my words of being involve in the politics. (Shrestha, 2060:133).

She was ready to lead with the interest of general leader works. Although the leaders of the party had taken her as the leader, she had not been in any post. She had got the leadership without any post. About this she says:

At that time I didn't have any post in the party. Only orator Balram Upadhya was there. I was just working as the Politburo, but everyone used to follow me. At that time I could be anything but I didn't be in any post. (Shrestha, 2060:139)

Although Sahana Pradhan seemed to take the leadership of party as subordinate thing for this Pushpalal's death seems to be the cause rather than her liberality.

After the death of Pushpa Lal though on the name of Sahana Pradhan, it was tried to give the continuation for the group by Balram Upadhya the success could not be gained. However, there was the same situation in the party which was run by Manmohan Adhikari. Manmohan Adhikari and Sahana Pradhan had the relationship of brother-in-law and sister-inlaw. When Pushpalal; was alive they couldn't have the good relationship due to personal aspiration rather than the principle they follow.(Gyanwali, 2070, Baisakh 3). Principally, their parties were not in dispute and it would be better in integration and form strong. Along with it there would be the positive message. This was the reason that after the death of Pushpalal the party which lacked leadership and the party led by Manmohan Adhikari got integrated. Gauri Bhakta Pradhan (2062) talks about it as follow:

CPN (Manmohan Group) and the party which was led by Sahana Pradhan did not have any differences in their principle. It was not necessary and practical to have two parties with same polity, ideas and principles. To have the integration was only the option as there was not difference in policy, ideas and principle. (P $134-35)$.

It is seen that Communist parties in Nepal are divided due to the personal aspiration rather than the principle. In the integration of these 
parties it is seen that family relation has worked more that the principle. Gauribhakta Pradhan had the great role in the integration of these two parties.

Though Pushpa lal had enlarge the league, after his death there was no capable leader to lead the party. Manmohan Adhikari had the leading capacity but his league was weak. As it was possible for all to win through the integration of leadership and league, they worked out for the integration. (Upadhya 2070 Jestha 2). As the result, in 2042Bs Ashwin 13 and 14 in Patan extended meeting of Central Committee of both partied got the formation of the prepared committee for $6^{\text {th }}$ conference by having the dissolution of the central committee of party and give the responsibility of preparing program for Manmohan Adhikari and preparing the political report for Sahana Pradhan. The sixth conference held in Sarnath, Banaras in 2043 chaitra, by integrating party kept the name CPN (Marxism). Manmohan got the post of General Secretary and Sahana Pradhan got the responsibility of Secretary. (Daily diary Saptahik 2013, Chaitra 18, Wednesday). After that Sahana Pradhan for the first time started to take the responsibility of party being in the post.

Four members committee including Manmohan Adhiklari, Sahana Pradhan, Madan Bhandari and Madhav Nepal was formed by preparing the manifesto related to the integration oif two parties on Mangsir 27 at the time of integration between two parties CPN (Marxism) and CPN (UML) which were working under Leftist Union during the people's movement in 2046BS. Sahana Pradhan had proposed not to keep any name after the name of party while the parties were int eh process of integrating and the supporters of the UML were demanding to keep the same name UML which was popular among the people but it was denied. Finally, CPN (United Marxism and Leninism was kept. Supreme source of the party which was formed after the integration of both parties was named as National Council and Central Committee and Politburo were included in it. Sahana Pradhan was the single lady to be the Politburo member (KC, 2060:99). That party had led the government by being the largest party in the country.

In 2051BS. CPN (UML) got the opportunity to lead the government. The party could not manage the situation between the government and the party. The voice of dissatisfactio0n were started to be raised as the position holder were rulers and the workers in party were ruled. As the result, as the party was excluded from the government unlucky signals were started 


\section{SAHANA PRADHAN IN THE POLITICS OF NEPAL}

to be seen. The post of Vice General Secretary was dismissed which was created without preparation and long lasting effect. Along with the post, while the issues of self respect of leaders was raising up groupism from ML time was gradually started to be widen. The decisions in the party were started to be on the basis of groupism rather than the quality. Mahakali treaty is one of it's example. The sixth conference of party was going on at the time of the fight between low capitalist which was growing up from the leadership, Feudal culture and leaders. The conference gave high focus on leadership rather than policy. That's why even by being at conference hall and participating in the all process at the time of selecting leadership the task of rejection was done. The moment of being back from the conference, Sahana Pradhan has described it as "When we were back to Kathmandu after the completion of conference, Madhav Kumar Nepal, Manmohan Adhikari we were together but we didn't talk, we were silent as if we were back from funeral procession." (Shrestha, 2060:194). After being back from the conference there was the discussion for many times but someof the leaders said "Why not to be happy if the things are wiped away itself which are needed to be swept". Some of said "We should not tolerate the injustice in Communist Party". Because of such thinking in 2054BS Falgun $21 \mathrm{CPN}(\mathrm{UML})$ got divided.

When the leaders from both side returned back from the conference they were in their own opinion. It seemed to have all the attempt of conciencing as to show. As the result in 2054, Falgun 11 Sahana Pradhan along with some other leaders seemed to be sure to divide the UML. To stop this it was decided to make the ten leaders including her out from the membership of UML according to the legislation of the party(Prashit 2070 Shrawan 13). On the same day in Secratariat Parliament Singhadarbar, by dividing parliamentary party registered the sepeate parliamentary party of 46 members. After the seven days of division on Falgun 28 in Sahana Pradhan's presidency it released the new central league name list of new central league (Janaastha Saptahik, 2054 Chaitra 5). It was not benifitted to anyone by the division of the party which was popular among the public. but personally, Sahana Pradhan had created the new history. In Nepal history she was success to register the name as the lady to be in the chief post of the party. There was no situation oa appreciating her work as she was standing for the post to fulfill the dreams of Pushpalal despite the difficult situations being his wife. 
The split of the party can be taken as the most unsuccessful part of Sahana Pradhan's life as she was in the post of president by unity divided Leftist party as the Leftist Union (Bhusal, 2075 Asar 31). However, Sahana Pradhan was not the single responsible part for this situation. It was also said that she was used by other people as she had been in the political height. If it is si, it is also her weakness.

The ML party which was formed by the division of UML party was gradually being doenb in the concept of public.though there wsthe revolutionary agendas at the time of division, there was no implementation of it. Most of the leaders who were excited for the division of party rejoined the old party as they got guilt on it.

Congress party turned out to be the larget party as the party couldnot win even a single seat which had committed to be the larger party than UML abd lead the government rather because of it, UML also got lost. As the result not only the general public but the workers at the party also started to have the negative impact about the party. Sahana Pradhan along with her leaders rejoined the UML party within 4 years of the division in 2058BS Falgun 3 by being convienced that the party can't move a head in such circumstance. UML had taken it as the important achievement (CPN UML, 2059, Chaitra:41). After the evaluation of all these situations, Sahana Pradhan's view is as follow:

I can remember I used to play at the bank of river by making the house of sand. I remember that my house used to fall down while making it and I used to destroy it $\mathrm{h}$ house made by my friends when I got angry with them. And I think that we have made the same type of house. (Shrestha, 2060:195).

It is clear from the above statement that political leaders get decision without thinking about the long term rather they come in the reprimand and show other. This type of decision would not benefit anyone. It is clear that not only the leaders rather general public too have faced the consequences.

When Soldier general Jiyaulhak came in power in neighbour counter Pakistan in 2035BS Chaitra 22 Julpikar Ali Bhutto was given death penalty. The death penalty given to Julfikar Ali Bhutto was known in all over the world. Everyone started to pay attention on this wvenrt. In Nepal in Chaitra 24 the police attacked the students who went to Pakistan Embassy Lazimpat to give complain letter Government felt the rally and the complain 


\section{SAHANA PRADHAN IN THE POLITICS OF NEPAL}

letter as the challenge to their prestige and treated against them. The death penalty for Bhutto in Pakistan became the foundatiuon of the movement for students in Nepal. While the students' movement was gradually going on all over the country in 2036 BS Baisakh 13 the Shahi Commission which was formed in the presidency of Dhanendra Bahadur Singh the Judge of supreme court to enquiry about the students strike, had a talk and did the agreement or fulfilling 13 demands. (KC. 2064:118). Although on the basis of that agreement, they came up with the statement requesting to stop the strike and get involved in the study, students continued it. As the result, in 2036 Jestha 10 King was obliged to announce the collection of Public opinion. During the period, there were total 14 big and small Communists groups (Panta, 2068:109). They couldn't form single opinion regarding the public opinion. CPN with Sahana Pradhan took announcement positively. Her opinion towards the announcement was as follow:

CPN expresses its agreement upon the national referrendom happening in Nepal through the central committee meeting in ordert he shoulder to the real decision taken by people in between Panchayati System and Multi-party system (Pandey and Shiwakoti 2036:11).

As the announcement of taking public opinion collection positively, even in the working policy from the past, the united movement with democratic power was changed in widened multiparty democratic unity (Ghimire, 2037:17). The power which was in the position started to cheat when the both multiparty and partyless started to perform actively to bring the public opinion on own's side. In 2036BS Bhadra 4, Sahana Pradhan, Nirmal Lama, Bharat Mohan Adhikari and other 8 people signed the 5 points statements to have the discrimination free collection of public opinion which aimed to make itnull (Rawal, 2047:183-84). That statement created the tossing environment. But Sahana Pradhan by forgetting those 5 points told that she was ready to particvipati in Public opinion collection though the 5 points weren'; fulfilled. (Jwala Saptahik 2036 Shrawan 19). It ws because of the behaviour shown by the leaders who had signed. At the time of promoting public opinion collection party has organized the 62 big and more than 200 small conferences (Ghimire, 2037:43) Sahana Pradhan had said she had been to the many places in Terai and not been to Far western for the conference(Shrestha, 2060:126). While promoting, in most of the area there was the fight among Leftist and Multiparty supporters for which she couldn't take it easy. 
The result of public opinion collection couldn't come at the side of multiparty as there was no unity among multiparty supporters and the cheating environment among partyless supporters. Political parties who were being open at the time of promotion of public opinion collection were again at the stage of banned.

Political parties which were in the form of banned were against the panchayati system. However, they were not being able to perform the movement actively. Because of which it was seen as if the objection was done only for the sake of objection. But still they hadn't stopped the movement. Nepali Congress in 2042 BS came on the field of Mo0vement by aiming to change the system through the civil disobedience movement.

As the Leftist were divided into various groups through their own insights, they were deciding whether to participate of not in the movement. Sahana Pradhan on the forst day asked for the suggestion to the leader of Nepali Congress Krishna Prasad Bhattarai how she could help. But he replied - "We will run this civil disobedience movement. We are going to sit at a door to foirce payment infront of Singha darbar, Charkhaal Adda, Suporeme Court. Don't be with us in this area. If you want to do, choose the area except these three areas". As she got this type of answer her interest remained nomore. But when some of the leaders from the party asked for her presence, she had participated the movement (Shrestha, 2060:141). The behave of Nepali Congress was responsible for not creatring the open environment to do the movement. The statement which was given on the fiorst day for the sake of helping movement was against the care of movement. However, she gave priority to the movement against the Panchayati system and participated in the movement and got arrested. The movement was stopped when the bomb attacked held during the civil disobedience movement was going on.

Although the CPN formed in 2006BS it remained as the same party till 2021BS, it got split in many groups. Because of that Leftist couldn't perform movement in national level. However, in the comparision to 2021BS, inb 2046BS Leftist politics has reserved the positive space among the young generations. Principallay, the aim of Leftist was not democracy rather communism. Eventhough for the aimed public movement against Panchayati system all among the except groups it was felt the need of accepted encironment form all sides. After knowing such trend of opposition, 


\section{SAHANA PRADHAN IN THE POLITICS OF NEPAL}

it was natural and simple for the Panchayat to encourage for fight and take the advantages form it. However, it was impossible to have the same time.

The perspective of looking one another was changing between the parties which were in the stage of banned. International circumstance was also being in the favour of panchayati system. In movement by aming to integrate the power of Leftist, in 2046 BS Magh 2 there was the formation of united leftist union of seven leftist groups(Menifesto of united Leftist 2047: 1-6). United Leftist Union could be formed by realizing Pushpalal's view of having the unity between democratic power and leftist power against the Shahi steps of 2017BS (Bhattarai, 2066:81). Sahana Pradhan was selected for the president of that union. Regarding the seniority, Manmohan Adhikari should be the president of the leftist union which was going to form for the first time. But practically, it was thought that it would be easy to be included in leftist union for marxism party as Sahana Pradhan get seated as the president. As Sahana Pradhan's name ws joint with Pushpalal founder general secretary of Nepal Communist Party, she was not criticized. Surendra Kc has also ,mentioned that Sahana Pradhan got the opportunity of being presiden as she was Pushpalal's wife (KC, 2065: 216-17). For which Sahana Pradhan has her own view:

I got all having the positive view regarding that leftist union. In leadership too there was no disagreement and dispute. My leadership was accepte may be because I have not done any bad works in my political work! I also feel that it is because Mr. Pushpalal's contribution and the political leadership in Communist Movement but I feel difficult to answer accurately (Shrestha, 2060:150).

While analyzing the above statement in the dispute situation of accepting others leadership and the stage of split because of the effect of leaders own over ambition it was easy for her to be president as on the side she was the wife of Pushpalal and on the other side she was active in the politics incomparision to female leadership.

Government started to arrest the people who are involved int eh movement, leaders, workers as Nepali Congress and leftist union got to get the movement together. Telephone lines were cut out from the leaders to make them contact less. Sahana Pradhan was arrested on the first of Falgun. Around 1500 people were arrested. However, members of formed committee to run movement were already underground, before the government arrested the leaders (Adhikari, 2055:333). Parties who were banned came on the 
road by demanding the reestablishment of democracy since Falgun 7. On the day of movement, in the various places of the country many people were killed and got wounded in Chitwan, Tanahau and Palpa as there was the fight between agiatator and police.

It was the first time the banned parties performed athe movement by integrating the working field against the panchayati regime system. It had been being easy for the ruling side as the banned parties were getting seperation from eachother. By aiming to give it the continuation ruler blamed by saying sheep's skin worn extrimist communists are involved in ciolence and breaking as fox in the name of peaceful movement (Gorkhapatra, 2046 Falgun 14). The movement against regime power was not performed only by communists rather it was the integrated movement. But also ruling side by promoting that there is the more involvement of communists in movement, was trying to collect the support in international level. By being afected from it Congress leader Prakash Koirala gave the statement of stopping the Public movement. However, before starting the movement Sahana Pradhan had given the focus on the opinions like - the movement should be made final and decisive whatever the base are, during the movement one should not stop in the temptation of ruling side, the final aim should be the reestablishment of democracy (Saptahik Nepali Aawaj 2046, Mangsirr 23). As the result, being in the jail Sahana Pradhan had requested all not to be confused by following the gossip of palace as the movement is helding ahead.

As the effect of increased Public movement in country had been hampering the life of people, there was the trend of open letter and change in council of ministers from palace. Last time on $24^{\text {th }}$ Chaitra, by appointing Lokendra Bahadur Chand in Prime minister's post, Cabinet was given the instruction to solve the problem by having a talk with politicians from various views. (Dhakal, 2049: 107-8). Although the change of council of ministers affect king and Panchas it worked as the additional support for the agitators. Sahana Pradhan who was been furious after the announcement of the king requested all to make the movement success. Infact, there was rallies by saying Shahi announcement is a lie. As the result on Chaitra 26 , there was reestablishment of democracy as there was the agreemetn between palace and agitator.

To be in jail is not the different thing for the people who are involved in politics. But Sahana Pradhan was in jail for some days in her student life 


\section{SAHANA PRADHAN IN THE POLITICS OF NEPAL}

in 2004 BS as she fought against Rana rigime. CPN did the movement against king's steps in 20098BS. Sahana was in jail for 4 months as she was arrested while participating the movement. She got jailed for 5 months in 21042BS by participating in Civil disobedience movement. In 2046BS she was arrested in Falgun 2 and was free in Chaitra 25 in the united movement. In this way, Sahana Pradhan seems to have jail for many times though the period was short.

Public movement of 2046 obliged king to have the reestablishment of democracy interim government had to be formed to run the country according to the new political events. Ganeshman Singh was proposed to take the leadership of government from the palace but he proposed Krishna Prasad Bhattarai due to his health problem. After that in 2047 BS. Baisakh 6, 11 members cabinet was formed in the recommendation of Krishna Prasad Bhattarai as he was appointed on the post of primeministers by king. In the cabinet four from Nepali Congress including prime mininsters, 3 from leftist union, 2 representative from king and 2 non-aligned people were included. Sahana Pradhan was also one of the participant in government who was from leftist unionn. She had handled ministry of Industry and commencewho was in government as the second position. She had got the opportunity to be in the government on coming days. She had handled the responsibility of Ministry of women, children and society welfare in 2053BS. Likewise, she had been the Deputy - Prime and Fopreign Affair Minister in 2062BS. She was the first Communist women minister to be in that level. The country had been badly hovering in Politicval instability from 2052 BS to 2062BS. People were infamous int their activities being at the post. Not only this, they were active to make the parliamentary management fail. But there was no situation to regret for Sahana Pradhan personally by involving in any activities. Sahana could make herself stand as the responsible leader, that was her strong side.

\section{CONCLUSION}

Doing politics is determined by events and situation. The participation of Sahana Pradhan in movement against the Rana regime is one of the best example. Although the democvracy was established in the country beind together (king and public) by doing the movement against Rana regime in 2007BS king himself snatched the democracy in 2017BS. Movement had to be done for a long time to reestablish the same democracy. Because of the movement in 2046BS, democracy was reestablished. Sahana 
Pradhan was in the lead role of the movement rather than the agitators. The achievemetn after the movement was also the gain of the power. She had been in the government when the agiatating power goit the opportunity to lead the government. This is the first time leftists have been participated in government. This was the great success and it seems natural to give the credit to Sahana Pradhan as she had led the leadership. Politics has the days of ups and downs due to which days were passign on based on hopes and disappointment . the satisfactioin which was felt being the leader of the UML party trusted by the public changed into disappointment when she become the president of ML by spliting the party. Sahana Pradhan's political life is the good example of getting the post due to the hard work and getting disappoinment while working for the post.

\section{REFERENCES}

Adhikari, SM. (2055). History of movement of democracy in Nepal. New Dellhi: Nirala Publication.

K.C., S. (2060). History of communist movement in Nepal. Kathmandu: Students Book Bhandar.

---- (2064). Past and present movement of communist in nepal. Kathmandu: Pairabi publication.

---- (2065). History of communist movement in Nepal. Vol. III Kathmandu: Students Book Bhandar.

Khanal, J.N. (2068). Nabayug monthly. Kathmandu: UML. P:7-10. Anka 22.

Gyali, G. (2065). Puspalal in samakalin history. Kathmandu: Ratna Pustak Bhandar.

Ghimire, K. (2037). Janamat sangharah \& samasamik left politics. Kirtipur: Unpublished thesis, Central Department of History, Kirtipur: TU.

Delly diary Weekly.(2043). Budhabar: barsha 4. Chaitra 18.

Janastha weekly. (2054). Barsha 3. Anka 51. P. 1.

Jwala Weekly. (2036). Sharawan 19. P. 1.

Dhakal, B P. (2049). Janaandolan 2046, Lalitpur: Bhupendrapurush Dhakal.

Tumbahamphe, S M. (2059). Movement of women in Nepal 2004-2046. Kathmandu: Association of Akhil Nepal Mahila. Retrieved form www.the kathmandupost.com.np published 23-09-2014 09.27. 
CPN-UML. (2059). Political and organization report of seventh AGM of $C P N-U M L . K a t h m a n d u$ : Central Office CPN-UML.

Panta, Y R. Sibakoti, B K. (2036). Nepal patra buletin. No.1. P11.

Panta, N P. (2068). National people participation, BS 2037 \& movement of democracy of Nepal. Kirtipur: Unpublished thesis, Central Department of History, Kirtipur: TU.

Pradhan, G. B. (2062). Mera samjhanaharu. Kathmandu: Pramesh Pradhan.

Bhattarai, S. D. (2066). Bradiyako Jangalma sagain alapatra. Nabayug Monthly. Barsha 20. P81 Kathmandu: CPN-UML.

Shrestha, S. (2060). Sahana Pradhan smreetika aankhijhyalbata. Kathmandu: Swapnawatika.

Rawal, B. (2047). Communisum origin, movement and development in Nepal. Second Part. Kathmandu: Pairabi Publication.

INSEC. (2052). Women Participation in Politics. Kathmandu: INSEC, P54. Author.

Menifesto of United Cumunist (2046). P:1-6. Kathmandu: Author. 